Ethiopian Journal of Environmental Studies \& Management 7(4): 389 - 401, 2014.

ISSN:1998-0507

doi: http://dx.doi.org/10.4314/ejesm.v7i4.6

Submitted: April 07, 2014

Accepted: July 02, 2014

\title{
USES, DYNAMICS AND CONSERVATION OF TREE SPECIES IN NIAYES AREA, SENEGAL *FAYE, E., ${ }^{1}$ CLARK-BARRY, J.2 AND BOGAERT, J. ${ }^{3}$
}

${ }^{1}$ Université de Thiès, Institut Supérieur de Formation Agricole et Rurale, Département Productions Forestières, BP 54 Bambey, Sénégal

${ }^{2}$ POBox 1492 Springfield, MO 65801 USA

${ }^{3}$ Université de Liège, Gembloux Agro-Bio Tech, Unité Biodiversité et Paysage, Gembloux, Belgique

\begin{abstract}
African National Forest offices are implementing participatory approach for natural resources' management and conservation. Taking into account local knowledge is very important for this approach to be successful. Ethnobotanical information relevant to conservation, use and dynamics of 124 woody species from the shrubby-savanna in North-western Senegal were recorded through factorial (gender, age and ethnic group) interviews with 108 villagers. Data were collected through informed consent structured interviews in a semi-quantitative approach. No significant difference between factors was found unless for sauce use. Close coincidence between species'local conservation priorities and their multipurpose status, particularly edible fruits, was indicated. Four classes of species were identified by principal components analysis confirmed by local priorities and Cultural Importance index (CI). Eleven species addressing directly the most important needs of local people according to 45 to $66 \%$ of the interviewees including local fruit trees established the first class. These species provided a $\mathrm{Cl}$ between 5.5 and 7.7 which is largely higher than those of the following three classes. Numbers of all species were considered by people to be declining mainly due to cutting and ploughing. But the most declining group was that of the class 1. Therefore, any sustainable biodiversity and agrobiodiversity conservation strategy, should try to stop this degradation trend using local preferences as main criterion for selection of species to plant for the well-being of rural population.
\end{abstract}

Key Words: Senegal, Niayes, shrubby-savanna, tree biodiversity, Ethnobotany, Conservation

\section{Introduction}

Natural vegetation and flora of some regions in Intertropical Africa have been damaged (Floret and Pontanier, 2000 and 2001) because of drought and anthropogenic activities such as agriculture, overgrazing, bushfire, etc. In Senegal, 80000 ha of forest are damaged yearly, meaning $1 \%$ of the total forest area (Diouf et al., 2001). Senegal has lost about $20 \%$ of its floral resources from the years 1980 (Diouf et al., 2001). This contributed to fragmentation of forest ecosystems determining diversity deterioration (Hill and Curran, 2005; Cramer et al., 2007) and low tree density in cultivated areas (Sall, 1996). Currently, farmers perceive declining biodiversity as caused by climate change (Lykke, 2000), particularly decreased precipitation. Northern littoral region of Senegal which is becoming

*Corresponding Author: Faye, E.

Email: hadjfaye@yahoo.fr 
one of the most important market gardening zones $(80 \%$ of the Senegalese market garden produce) where heavy anthropogenic pressure occurs, has its flora diversity seriously threatened (Guèye, 2000).

In this context of heavy threat on flora, farmers are also concerned with restoring landscapes through biodiversity conservation to enhance local diversity in agrosystems and compensate for local high intensity management (Tscharntke et al., 2005). Through this effort, agriculture can contribute to the conservation of highdiversity systems by providing important ecosystem services such as pollination. But achieving that goal requires a particular approach encompassing the opinions of local people (Desert Margin Program, 2004) thus exposing the socioeconomic importance of tree uses (Lyke, 2000; Giday, 2001; Ganaba et al., 2005; Mitinje et al., 2006). To maintain durable high-diversity agrosystems, agricultural policies must take into consideration the following factors: local knowledge, uses and priorities on biodiversity (Adams and Mcshare, 1992; Meffe and Caroll, 1994).

The main objective of this study was to determine most important species for conservation through ethnic groups and gender in relation with socioeconomic needs of local people and to assess trend of variability of those species in the area.

\section{Methodology \\ Study Area}

The study was carried out in the middle Niayes which represents the Senegalese north western Atlantic coast from Dakar to SaintLouis (Figure 1). The term Niayes designates in Wolof (major ethnic language in Senegal) the palm groves of Elaeis guineensis in the coastal depressions. The climate is the Subcanarian type, characterized by maritime winds blowing from the north from December to May and causing a relatively low temperature during this period. The higher monthly maximum temperature occuring on July-August is on the average between $27.5^{\circ} \mathrm{C}$ and $28.1^{\circ} \mathrm{C}$. Annual precipitation is between 300 and $500 \mathrm{~mm}$ with the heaviest rainfall recorded during august. The very short rainy season (July to September) proceeds from the influence of the monsoon. The maritime trade winds drag the coastal sands away and reform dunes.

This littoral zone includes white dunes and the continental area semi-fixed yellow dunes and fixed red ones (Direction des Eaux et Forêts Chasse et de la Conservation des Sols, 1999). According to Giffard (1974), the Niayes region belongs to the Sahelian domain. It is a biologic crossroads characterised by a floristic complex combination of both Guinean and Sahelian domains. Distribution of the Niayes subguinean Elaeis guineensis palm groves' depends on water table depth and salt content. Red and yello dunes are covered by shrubby-savannas. 


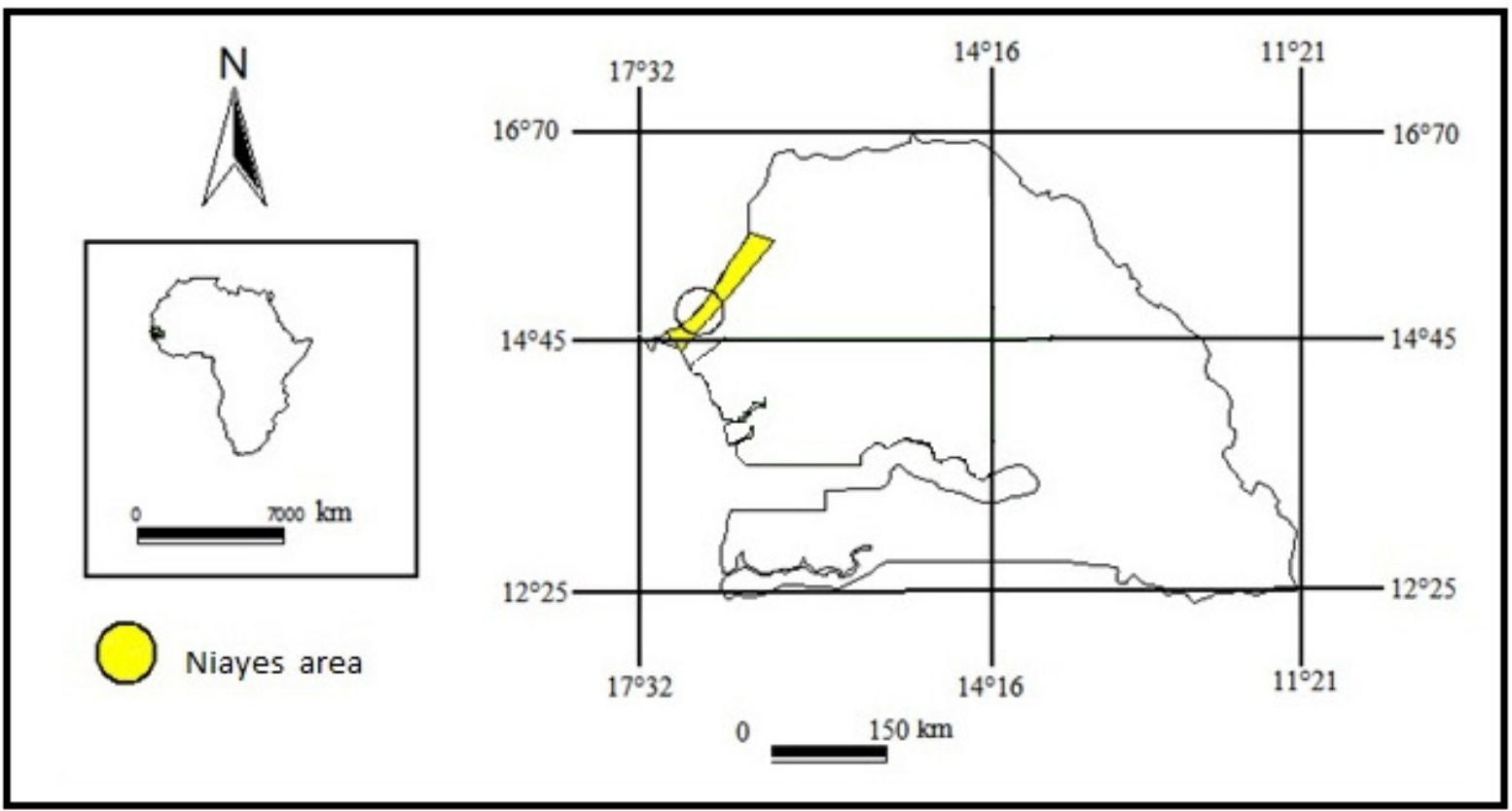

Figure 1: Map of the Niayes region in Senegal

\section{Material and methods}

Three villages were chosen for their ethnicity in this region: Diambalo (Wolof village), Darou Alpha (Sérer) and Toula (Peul) belonging respectively to the district of Tivaouane and district of Thiès. These are three villages that satisfied all the criteria of selection such as ethnic groups, types of dunes (yellow, read and white), receptiveness of local populations and main land use systems. A total of 108 persons were individually interviewed based on a questionnaire and they were categorized into mature adult class (more than 50 years old) and young adult class (less than 50 years old) while considering two genders and three main ethnic groups. Equal number of informants (fifty-four) were selected per gender. The mean of subsistence of the interviewed people is mainly agriculture, stock and truck farmings, arboriculture as well as commerce and pharmacopeia.

The assessment included question on 124 native wild woody species selected from the flora of Berhaut (1967) and completed from additional informations given by local people during pilot testing. For each category and each species, data were collected through informed consent structured interviews with local informants. A semi-quantitative approach was used to document the relative importance of each species as following: $0=$ no importance, $1=$ moderate importance, $2=$ high importance, $x=$ no opinion. Priority for conservation of each species was documented as following: $0=$ no priority, $1=$ moderate priority, $2=$ high priority, $\mathrm{x}=$ no opinion. For each species, local name corresponding to the ethnic group was used for testing knowledge of the species (no=0; yes $=1$ ). If answer is yes, then respondent was asked to answer on other topics. Local knowledge, uses, dynamics and priorities for conservation data on the 124 tree species of the Niayes' agrosystems was then obtained and recorded.

The matrix 124 species X 13 variables (conservation priority, edible fruits, medicine, commerce, sauce, fodder, firewood, construction wood, field trees, decline, increase, past and actual status) contains frequency of respondents through valuation indices $0,1,2$, x. Data processing 
aimed at comparing gender, ages and ethnic groups effects by Spearman rank correlation, and bringing out classes of species according to priority for conservation (as valued by the respondents) in relataion with principal components analysis (PCA) and cultural significance (CS) of each species (Pardo De Santayana et al., 2007) for which every plant species mentioned by an informant within one use-category was counted as one usereport (UR). To estimate this CS, we used the Cultural Importance Index (CI), calculated with the following formula (Tardio and Pardo De Santayana, 2008):

$\mathrm{CI}=\sum_{\mathrm{i}=1}^{\mathrm{NU}} \frac{\mathrm{UR} \mathrm{i}}{\mathrm{N}}$

The index was obtained by adding the $U R$ in every use-category ( $i$, varying from only one use to the total number of uses, $N U$ ) mentioned for a species, divided by the number of informants in the survey $(N)$. Only species mentioned by at least one respondent were considered.

The matrix 124 species X 13 variables was then split into six sub-matrices: one based on
8 use categories and conservation priority, one on 4 dynamics categories, one on 4 causes of dynamics and three based upon 3 ethnic groups, gender and 2 ages. These six matrices were used one by one to perform Spearman rank correlation tests. The Spearman test verified linkage between different use categories, and various ethnic, gender and age groups. For overall analysis, the matrix 124 species $\mathrm{x} 8$ uses were submitted to principal components analysis (PCA).

\section{Results}

Identification of Classes of Conservation Priority

Multivariate analysis (PCA) applied on 124 species $\mathrm{x} 8$ uses discriminated four groups of multipurpose tree species (Figure 2 A). Fruit trees were placed in the positive quarter of the factorial map in opposition with the majority of species which combined or not edible fruits and multipurpose status (Figure 2 B).

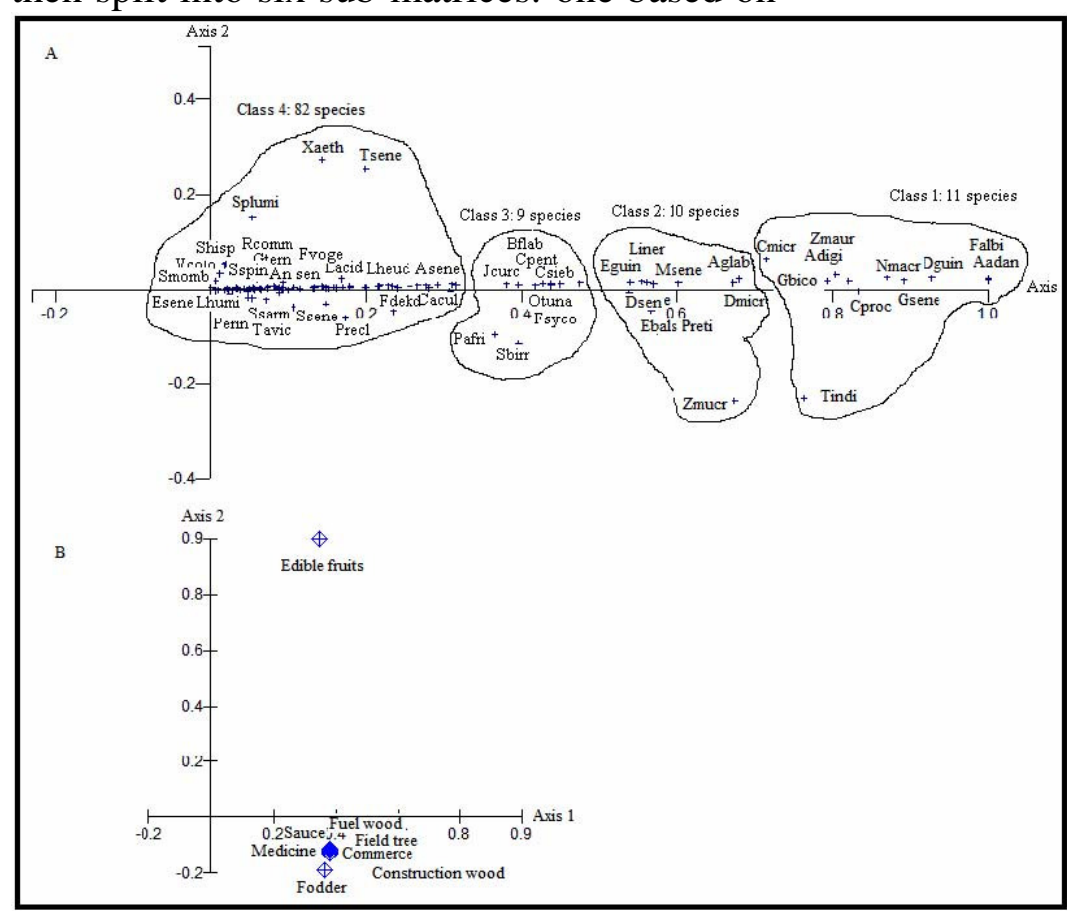

Figure 2: Principal component analysis on 124 x 8 uses matrix: A map of the species and B map of uses (complete names of species in Table 1). 
These above mentioned four classes of species run in connection with local consensus expressed in figure 3 on which were represented high priority species for conservation according to $45-66 \%, 20-44 \%$, $10-19 \%$ and less than $10 \%$ of the respondents respectively for the classes $1,2,3$ and 4 . These levels of priority seemed to be bound to the interest that each class of species represents. Indeed, all species represented in figure 3 class 1 had significance (assessment level 2) as commercial, fodder (except Combretum micranthum), medicinal, food (except Faidherbia albida), fuel wood and as field tree species. By far, respondents all valued fruit-bearing species most over any other category. Only three species were highly valued for sauces (Tamarindus indica, Adansonia digitata, Elaeis guineensis). Faidherbia albida was valued most as fodder and as a field tree. Acacia adansonii was the most valued medicinally and as fuel wood. Tamarindus indica, Adansonia digitata, Ziziphus mauritiana, Neocarya macrophylla and Dialium guineense were valued, in this order, fruit trees as well as commercial species.

It appears in figure 3 that species really well appreciated by inhabitants are in class 1 . The percentage of respondents having moderate or high importance for other uses was decreasing across the classes. Indeed in class 2, majority of interviewees gave $\mathrm{x}$ (no opinion) as answer for use categories. This report was more distinct within the classes 3 and 4.

In class 2, high priority profile (assessment level 2) dominated other valuation option (0 and 1) for Detarium microcarpum, Elaeis guinenensis and Lawsonia inermis; Annona glabra, Maytenus senegalensis, Detarium senegalensis were of moderate priority. Respondents in this category appreciated class 2 species for their fruits, fuel wood, pharmacopoeia interests and to a lesser extent for fodder and commercial values. Sauce, construction wood and field tree uses had little importance in this category of species (Figure 3, class 2).

The third class of species (Figure 3, class 3) was awarded importance by the respondents for use categories like edible fruits, field trees and commerce (Borassus flabellifer, Cocos nucifera), fodder (Celtis integrifolia), and fuel wood with a relatively homogeneous importance to all species. Fourth class of species were of litte interest for conservation according to interviewees except for edible fruits and commerce (Annona senegalensis and Landolphia heudelotii) and for fuel wood (Prosopis africana). No respondent considered of great conservation priority the last 74 species which are not represented in figure 3.

The Cultural Importance Index (CI) higher in class 1 than in any other class showed decreasing importance of species through classes and confirmed definition of classes and priority of species as bound on socioeconomic value (table 1). Maximum CI difference between first and second classes was 3.6 while it was 4.7 with the third class. CI in class 1 was twice CI in class 3 and from 2.6 to 76 times CI of last class (Table 1). 
Uses, Dynamics and Conservation of Tree Species in Niayes Area, Senegal.

FAYE et al.
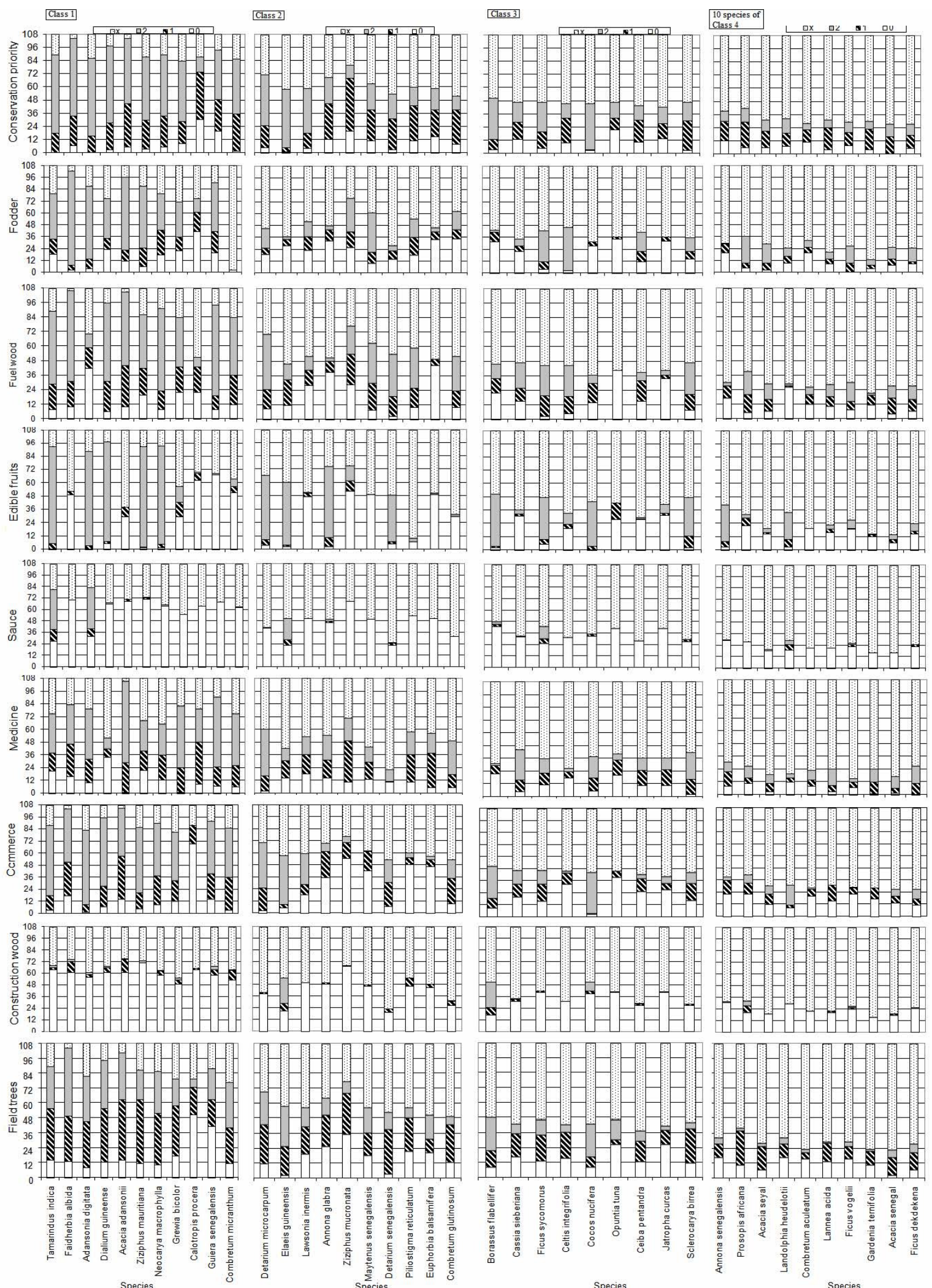

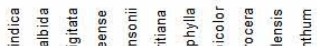

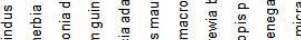

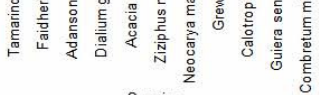

Figure 3: Importance for conservation and uses through the four classes of species defoesined by Principal Components Analysis 
Table 1: Classes and Cultural Importance Index (CI) of each tree species

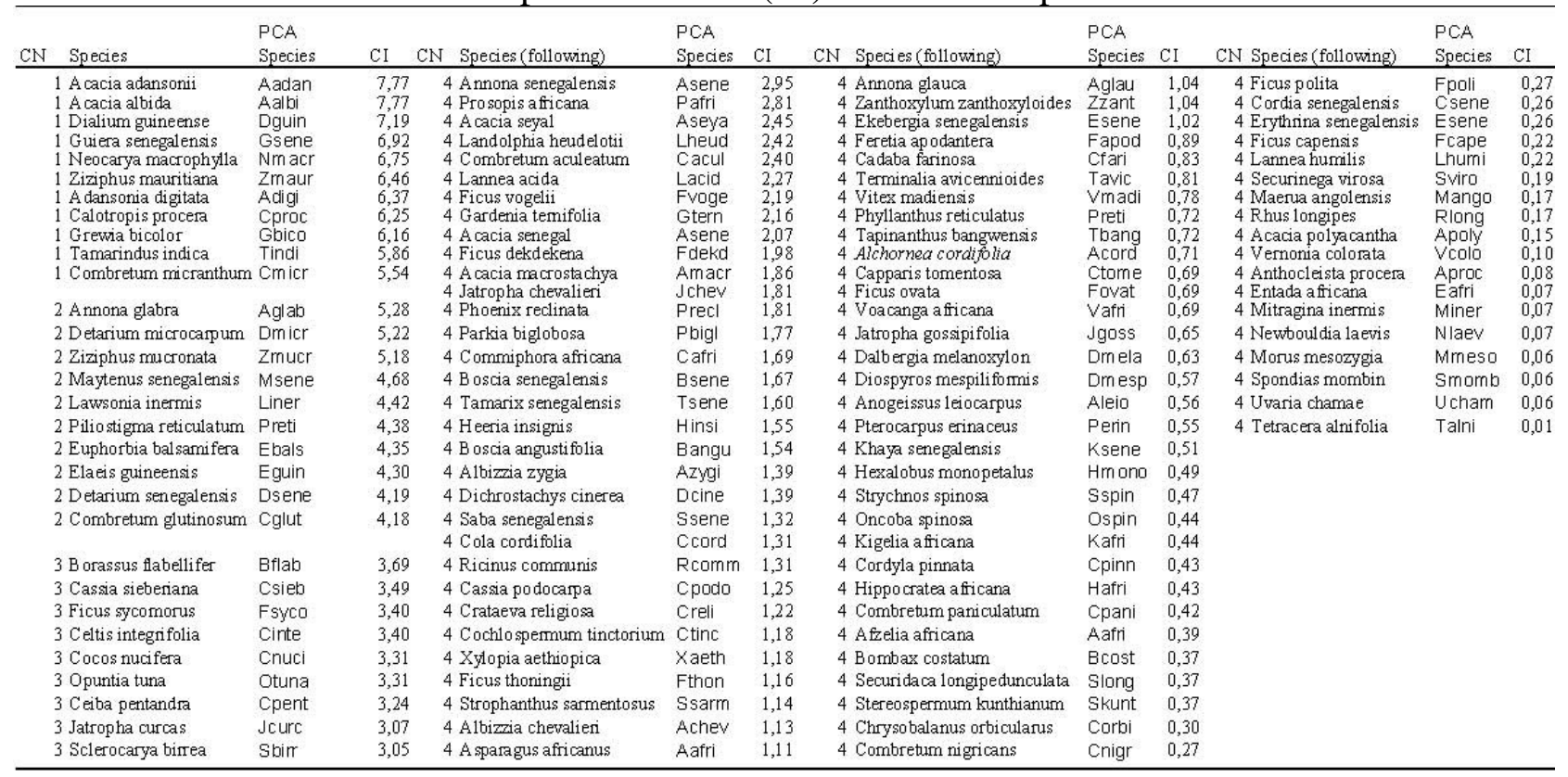

$\mathrm{CN}=$ class number; $\mathrm{PCA}=$ Principal Components Analysis

\section{Dynamics of species and causes}

All species of the above mentioned four classes were declining in the region according to the local people what ever the class was. As shown in figure 4 , the most declining species were those belonguing to class 1. These species were given an important status in the past (meaning high density in the past 70 years), and the most important among them were Faidherbia albida, Acacia adansonii and Adansonia digitata. Nowadays, occurrence of these species is lower. That means that people exploited species without taking any sustainability caution and most threatened species were Faidherbia albida, Ziziphus mauritiana, Grewia bicolour, Tamarindus indica and Adansonia digitata. However, Faidherbia albida, Ziziphus mauritiana, Grewia bicolor, Tamarindus indica, Acacia adansonii, Ziziphus mucronata still relatively well represented.

Figure 5 showed that cutting and ploughing are the most important causes on status (meaning situation of diversity in the past and nowadays) and dynamics of flora in agrosystem. Tree stumps burning and bushfire were considered of little occurrence by the majority of the respondents, so not decisive in the downward trend of species.

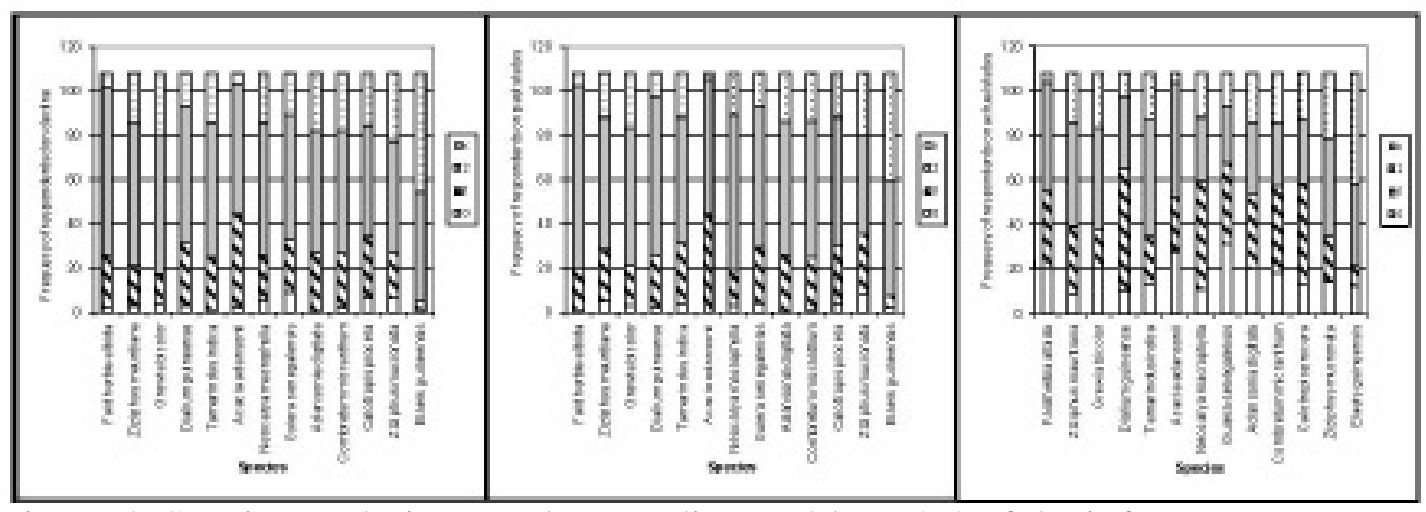

Figure 4: Species evolution trends according to 45 to $70 \%$ of the informants 


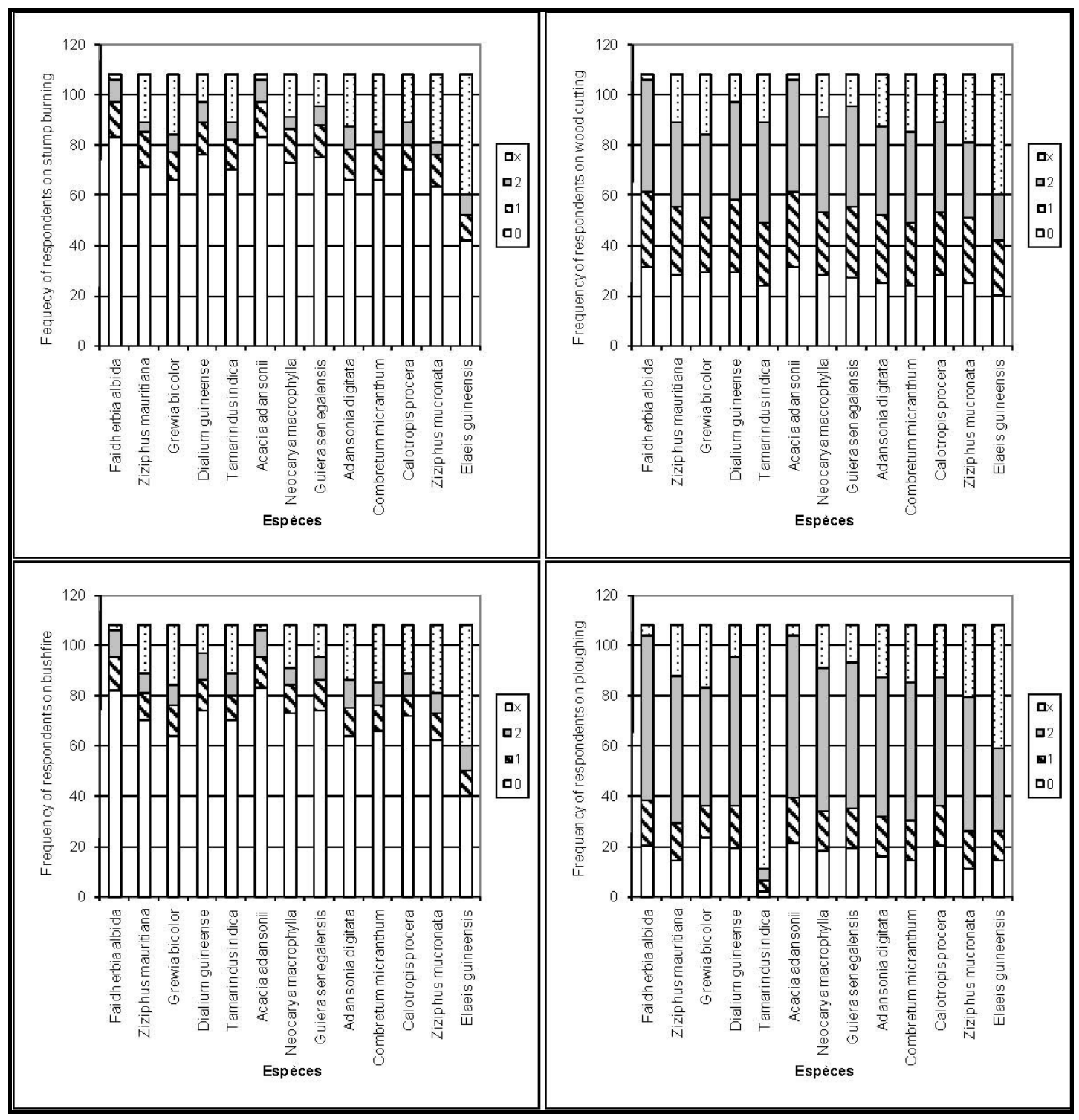

Figure 5: Importance of the factors of dynamics through response types

\section{Species conservation and uses in relation to} ethnic group, age and gender

Different use categories global analysis showed significant correlations between conservation priority of species and their uses. The species noted for different uses were correlated significantly at the Bonferroni corrected $\alpha$-level $0.13 \%$ (Table 2). These species were multipurpose trees.

The analysis of ethnic, age and gender factors effects showed significant

correlations between them whatever the category of use was except for sauce. On the species serving in sauce, correlations were not always significant between the above mentioned factors. For sauce use, ethnic groups were not similar in their choice of species at the Bonferroni corrected $\alpha$-level $1.6 \%$ (Table 3 ). 
Table 2: Spearman rank correlation coefficients based on species importance among conservation priority and uses categories

\begin{tabular}{llllllllll}
\hline Medicine & $0.97^{* *}$ & & & & & & & \\
Fuel wood & $0.98^{* *}$ & $0.96^{* *}$ & & & & & & \\
Fruits & $0.95^{* *}$ & $0.93^{* *}$ & $0.96^{* *}$ & & & & & \\
Commerce & $0.99^{* *}$ & $0.97^{* *}$ & $0.98^{* *}$ & $0.95^{* *}$ & & & & \\
Fodder & $0.91^{* *}$ & $0.88^{* *}$ & $0.90^{* *}$ & $0.88^{* *}$ & $0.91^{* *}$ & & & \\
Sauce & $0.97^{* *}$ & $0.96^{* *}$ & $0.98^{* *}$ & $0.97^{* *}$ & $0.97^{* *}$ & $0.90^{* *}$ & & \\
Timber & $0.97^{* *}$ & $0.95^{* *}$ & $0.97^{* *}$ & $0.96^{* *}$ & $0.97^{* *}$ & $0.90^{* *}$ & $0.99^{* *}$ & \\
Field tree & $0.99^{* *}$ & $0.96^{* *}$ & $0.08^{* *}$ & $0.96^{* *}$ & $0.99^{* *}$ & $0.90^{* *}$ & $0.98^{* *}$ & $0.98^{* *}$ \\
& Conservation & Medicine & Fuel & Fruits & Commerce & Fodder & Sauce & Timber \\
& & & & & & & \\
\hline
\end{tabular}

** Indicate correlation significant at the Bonferroni corrected $\alpha$-level 0.0013

Table 3: Ethnic effects on sauce use

\begin{tabular}{lll}
\hline Wolof & $0.31 \mathrm{~ns}$ & \\
Peul & $0.38 \mathrm{~ns}$ & $0.19 \mathrm{~ns}$ \\
& Sérer & Wolof
\end{tabular}

ns is non significant correlation at the Bonferroni corrected $\alpha$-level 0.016

All combinations of ethnic groups and ages factors were statistically different in species selection for sauce use except adult and young Peuls, and adult Peuls and young Sérers. These groups were significantly correlated at the Bonferroni corrected $\alpha$-level $0.3 \%$ (Table 4 ).

Table 4: Age and ethnic group interaction effects on sauce

\begin{tabular}{llllll}
\hline Sérsup50 & $0.45 \mathrm{~ns}$ & & & & \\
Wolinf50 & $0.38 \mathrm{~ns}$ & $0.34 \mathrm{~ns}$ & & & \\
Wolsup50 & $0.30 \mathrm{~ns}$ & $0.46 \mathrm{~ns}$ & $0.29 \mathrm{~ns}$ & & \\
Peulinf50 & $0.23 \mathrm{~ns}$ & $0.46 \mathrm{~ns}$ & $0.44 \mathrm{~ns}$ & $0.29 \mathrm{~ns}$ & \\
Peulsup50 & $0.51^{* *}$ & $0.31 \mathrm{~ns}$ & $0.23 \mathrm{~ns}$ & $0.24 \mathrm{~ns}$ & $0.50^{* *}$ \\
& Sérinf60 & Sérsup50 & Wolinf50 & Wolsup50 & Peulinf50 \\
\hline
\end{tabular}

** Indicate correlation significant at the Bonferroni corrected $\alpha$-level 0.003 ; ns, non-significance; Sér=Sérer, Wol=Wlof, Peul; inf50/sup50=less/more than 50 years

Spearman correlation rank test, when applied on a gender and use data table, showed a nonsignificance relation at the Bonferroni corrected $\alpha$-level $0.3 \%$ through the ethnic groups. Significant correlation was found only between Peuls (whatever the gender was) and Sérers women (table 5).

Table 5: Sex and ethnic group effects on sauce use

\begin{tabular}{|c|c|c|c|c|c|}
\hline Sérer men & $0.33 \mathrm{~ns}$ & & & & \\
\hline Wolof women & $0.46 \mathrm{~ns}$ & $0.40 \mathrm{~ns}$ & & & \\
\hline Wolof men & $0.35 \mathrm{~ns}$ & $0.42 \mathrm{~ns}$ & $0.41 \mathrm{~ns}$ & & \\
\hline Peul women & $0.55^{* *}$ & $0.49 \mathrm{~ns}$ & $0.38 \mathrm{~ns}$ & $0.36 \mathrm{~ns}$ & \\
\hline Peul men & $0.58 * *$ & $0.12 \mathrm{~ns}$ & $0.37 \mathrm{~ns}$ & $0.24 \mathrm{~ns}$ & $0.44 * *$ \\
\hline & Sérer women & Sérer men & Wolof women & Wolof men & Peul women \\
\hline
\end{tabular}




\section{Discussion}

The results assessed from our surveys hereto in have led to four classifications. Since species serving in different uses (except for the three sauce species: Tamarindus indica, Adansonia digitata and

Elaeis guineensis) present significant correlations with ethnical, gender and age, meaning no differences in species selection for the majority of studied categories, our analysis will rely only on overall classifications of species through use categories.

Class 1 holds the species most quoted by all ethnic groups, ages, genders for all studied uses in the Niayes area. According to Lykke (2000) results, they should present at the top of a free-listing of frequencies. Class 2 is also important but to a lesser extent; it devalues sauce, construction woods and field tree uses comparatively with Class 1 species. Most species of these two classes are edible fruits, and Ambé (2001) informs that fruit consumption is bound to distribution, availability and taste of species. These three conditions seem united in Niayes. That could increase pressure on species, and this pressure could worsen if some species and their trade and consumption network were well known. Indeed, apart from Adansonia digitata which food value is well known (Baumer, 1995), other species are also important nutritionally. For example Eromosele (1991) indicates that Ziziphus mauritiana calcium content is more elevated than in cultivated plants. Herzog et al. (1994) pointed out the $28 \%$ oily matter content in Annona senegalensis seeds. This fat matter could be transformed into oil and increase population pressure on the resource. Class 3 constitutes 18 species of relatively little importance that are almost homogeneous between use categories. However, this class doesn't consider sauce and construction wood. The species of this class are of interest as fodder, edible fruits, pharmacopoeia and wood construction. Class 4 contains the largest number of species (82) in relation to the three previous classes. Among these species Annona senegalensis and Landolphia heudelotii are the most quoted due to their fruit importance for the majority of the respondents that mentioned it. One might speculate Annona senegalensis could be in this class for two reasons: first because it is so rare or so abundant that people who knew it expressed their interest; second because it presents less interest for local populations. This last hypothesis seems most plausible. Indeed, currently, A. senegalensis fruit is consumed mostly by children (Vivien and Faure, 1995) and shepherds (Malgras, 1992), and its leaves ea Generally, Acacia adansonii is the most important medicinal species, Faidherbia albida the most important fodder and field species, Tamarindus indica, Adansonia digitata, Ziziphus mauritiana, Neocarya macrophylla and Dialium guineense are respectively the most important fruit and commercial species. All these species are in Class 1, which confirms their high priority for conservation. For all these species, edible fruit category is the most quoted. One may speculate on the effect of fruit exportation on species survival. One can see an aging of the species populations. But fruit use isn't an immediate threat to species perennity even if risk of decline is real without seminal and/or vegetative regeneration. In the case of Cordyla pinnata, from which fruits are almost entirely exported from fields to homes for consumption, one can note some damage today (Samba, 1997). For some other species of the shrubby-savanna of Niayes area such as Neocarya macrophylla, Dialium guineense, Ziziphus mauritiana, fruit exportation could be a factor of decline while populations mentioned only cutting and 
ploughing as main causes of dynamics particularly in class 1 . In the other hand, Giday (2001) showed that the leaves are most frequently harvested for medicinal use, but Poffenberger et al. (1992) showed that exploitation of $50 \%$ of tree foliage doesn't affect plant growth and thus is not threatening its survival. In this study global decline is controlled by comparing past and actual status of the species. Local people incriminate cutting and ploughing as principal factors of tree species decline in agrosystem confirming the statement of Faye et al. (2003) on the contrary of forest environment where bushfire is driving factor of the dynamics according to Lyke (1998) and Lykke (2000). Human factor seems to be most incriminated in biodiversity lost and climate change in density lost (Gonzalez, 2001).

The main thrust of this study shows that conservation priority decreases according to species classes. Importance granted in general to the same uses decreases from the first to the last class, and there is a strong relationship between uses and conservation. Generally, local populations don't propose species conservation in their area for pleasure but for clear socioeconomic reasons and because of resource scarcity. It appears that the greatest eligibility of species for conservation in the area is multifunctional as Hahn-Hadjali and Thiombiano (2000), Sadio et al. (2000) and Wezel and Haidgis (2000) said in other regions. That's why it is essential to agree with Ambé (2001) that the local populations' preferences must guide the choice of species to keep and to value. Other less quoted species, get less attention and are probably destined to disappear with the destruction of their habitat (Giday, 2001), which would, in turn, constitute a loss of diversity and threaten equilibrium in the ecological systems.ten by animals
(Nouvellet, 1987). Seed oil of A. senegalensis is not exploited in this region.

\section{Conclusion}

This research indicates the importance of socioeconomic benefits in species prioritization for conservation. Most conservation priority species are multipurpose trees. But interest in fruit crops plays an especially decisive function in species importance for local populations. Lesser quoted species are subject to extinction simply by non-priority and subsequent destruction of their habitat for the production of selected species, thus necessitating a backup plan for their preservation. Since gender, ages and ethnic groups have no significant effect on almost all uses (except for sauce), overall analysis shows a common interest of the people on the same species. Therefore the same measures should be promoted in shrubby-savanna environment of Niayes region whatever the village is because of relative homogeneity of opinion. Because of scarcity of all species due, out of climate change, essentially to cutting and ploughing, planting and protecting are necessary measures to implement in a participatory way from the vicinity to the limit of the village lands based on the 4 classes of species. These classes of species may be proposed to the programs of reafforestation undertaken by intervenors in this area both Governmental and Non Governmental Organizations.

\section{References}

Adams, J. S. and McShane T. O. (1992). The Myth of Wild Africa. Norton, New York.

Ambé, G.A. (2001). Les fruits sauvages comestibles des savanes guinéennes de Côte-d'Ivoire : état de la connaissance par une population locale, les Malinké. 
Uses, Dynamics and Conservation of Tree Species in Niayes Area, Senegal...............FAYE et al.

Biotechnology, Agronomy, Society and Environment 5: 43-58.

Arbonnier, M. (2002). Arbres, arbustes et lianes des zones sèches d'Afrique de l'Ouest. Centre de Coopération Internationale en Recherche Aagronomique pour le Développement/Musée National d'Histoire Naturelle, Paris.

Baumer, M. (1995). Arbres, arbustes et arbrisseaux nourriciers en Afrique occidentale. Enda Tiers-Monde, Dakar

Berhaut, J. (1967). Flore du Sénégal. Clairafrique, Dakar.

Cramer, J.M. and Mesquita, R.C.C. and Williamson, G.B. (2007). Forest fragmentation differentially affects seed dispersal of large and small-seeded tropical trees. Biological Conservation, 137: 415-423.

Desert Margin Program (2004). Les savoirs traditionnels de préservation des terres et de la diversité biologiques dans les sites de recherches du programme d'action sur les zones en marge du désert (D.M.P.). Rapport 007, CNRST, Ouagadougou.

Diouf, D., Neyra M., Sougoufara, B. and Lesueur, D. (2001). Le Plan d'action forestier du Sénégal : bilan et perspectives des activités de reboisement de 1993 à 1998. Bois et Forêts des Tropiques, 270: 5-13.

Direction des Eaux Forêts Chasse et Conservation des Sols (1999). Schéma directeur de la zone écologique du littoral et des Niayes. Food and Agriculture Organization/Bureau d'Information Formation et Sensibilisation, Dakar.

Eromosele, I.C., Eromosele, C.O. and Kuzhkuzha, D.M. (1991). Evaluation of mineral elements and ascorbic acid contents in fruits of some wild plants.
Plants Foods for Human Nutrition, 41: 151-154.

Faye, E., Masse, D. and Diatta, M. (2003). Dynamique de la régénération ligneuse durant la phase de culture dans un système de culture semi-permanente du sud du Sénégal. In: Jamin, J.Y., Seiny Boukar, L., Floret, C. (Eds), Savanes africaines: des espaces en mutation, des acteurs face à de nouveaux défis, Actes de Colloque, 9 p.

Floret, C. and Pontanier, R. (2000). La jachère en Afrique tropicale. Rôle, aménagements, alternatives. John Libbey Eurotext, Paris.

Floret, C. and Pontanier, R. (2001). La jachère en Afrique tropicale. De la jachère naturelle à la jachère améliorée. Le point des connaissances. John Libbey Eurotext, Paris.

Ganaba, S., Ouadba, J.M. and Bognounou, O. (2005). Exploitation traditionnelle des végétaux spontanés en région sahélienne du Burkina Faso. Vertigo, 6: 12-24.

Giday, M. (2001). An ethnobotanical study of medicinal plants used by Zay people in Ethiopia. Skriftserie 3, 81-99.

Gonzalez, P. (2001). Desertification and a shift of forest species in the West African Sahel. Climate Research, 17: 217-228.

Guèye, S. (2000). Etude sur les ressources forestières et les plantations forestières du Sénégal-Période de 1992 à 1999. Union Européenne/Food and Agriculture Organization/Banque Africaine de Développement, Dakar

Herzog, F., Farah, Z. and Amado, R. (1994). Composition and consumption of gathered wild fruits in the V-Baoule, Côte-d'Ivoire. Ecology of Food and Nutrition, 32: 181-196.

Hill, J.L. and Curran, P.J. (2005). Fragment shape and tree species composition in 
tropical forest: a landscape level investigation. African Journal of Ecology, 43: 35-43

Lykke, A.M. (1998). Assessment of species composition change in savanna vegetation by means of woody plants'size class distribution and local information. Biodiversity and Conservation, 7: 1261-1275.

Lykke, A.M. (2000). Local perceptions of vegetation change and priorities for conservation of woody-savanna vegetation in Senegal. Journal of Environmental Management, 59, 107120.

Lykke, A.M. (1997). Trees and shrubs of sahelian depressions: highly important but heavily threatened. Serein Working Paper 31, Copenhag.

Lykke, A.M., Kristensen, M.K. and Ganaba, S. (2004). Valuation of local use and dynamics of 56 woody species in the Sahel. Biodiversity and Conservation, 13: 1961-1990.

Malgras, D. (1992). Arbres et arbustes guérisseurs des savanes maliennes. Paris: Karthala/ACCT, 478 p.

Meffe, G. K. and Carroll, C. R. (1994). Principles of Conservation Biology. Sinauer Associates, Sunderland.

Mitinje, E.J., Kessy, F. and Mombo, F. (2006). Socio-economic factors influencing deforestation on the Uluguru Mountains, Morogoro, Tanzania. Discovery and Innovation, 18: 137-146.

Nouvellet, Y. (1992). Evolution d'un taillis de formation naturelle en zone soudanienne du Burkina Faso. Thèse Université Pierre et Marie Curie, Paris $V I, 356 \mathrm{p}$.

Pardo De Santayana, M., Tardío, J., Blanco, E., Carvalho, A. M., Lastra, J.J., San Miguel, E. and Morales, R. (2007).
Traditional knowledge of wild edible plants used in the northwest of the Iberian Peninsula (Spain and Portugal): a comparative study. Journal of Ethnobiology and Ethnomedicine, 3: 27-37;

Poffenberger, M., McGean, B., Khare, A. and Campbell, J. (1992). Field Method Manual, Volume II. Community Forest Economy and Use Pattern: Participatory Rural Apprisal (PRA) Methods in South Gujarat. IndiaSociety for Promotion of Wastelands Development, New Delhi.

Sadio, S., Dione, M. and Ngom, M.S. (2000). Région de Diourbel: Gestion des ressources forestière et de l'arbre. Drylands Research Working Paper 17, Drylands Research, Somerset, Great Britain.

Sall, P. (1996). Les parcs agroforestiers du Sénégal: Etat des connaissances et perspectives. Rapport de consultation SALWA, Dakar.

Samba, A.N.S. (1997). Influence de Cordyla pinnata sur la fertilité d'un sol ferrugineux tropical et sur le mil et l'arachide dans un système agroforestier traditionnel au Sénégal. Ph.D.Dissertation University of Laval, Québec.

Tardio, J. and Pardo De Santayana, M. (2008). Cultural Importance Indices: A Comparative Analysis Based on the Useful Wild Plants of Southern Cantabria. Economic Botany, 62: 24-39

Vivien, J. and Faure, J.J. (1996). Fruitiers sauvages d'Afrique: espèces $d u$ Cameroun. CTA, Wageningen,

Wezel, A. and Haigis, J. (2000). Farmers'perception of vegetation changes in semi-arid Niger. Land Degradation and Development, 11: 523-534. 